Web Jurnal:

http://ejournal.kemenperin.go.id/jli

\title{
Pengaruh konsentrasi tawas dan tunjung dalam limbah cair pengolahan gambir (Uncaria gambir Roxb.) untuk penyamakan kulit
}

\section{The Effect of alum and tunjung concentration in gambier processing wastewater for leather tanning}

\section{A Ardinal* dan Salmariza Sy}

Balai Riset dan Standardisasi Industri Padang

J1. Raya LIK No. 23 Ulu Gadut, Padang, Indonesia

* e-mail: ardinal_ok@yahoo.co.id

\begin{tabular}{l}
\hline INFO ARTIKEL \\
\hline Sejarah artikel: \\
Diterima: \\
19 November 2019 \\
Direvisi: \\
17 Desember 2019 \\
Diterbitkan: \\
30 Desember 2019
\end{tabular}

Kata kunci:

air limbah pengolahan;

gambir;

tawas;

tunjung;

samak kombinasi

\section{Keywords:}

gambier processing wastewater;

alum;

tunjung;

combination tanning

\begin{abstract}
ABSTRAK
Penelitian penyamakan kulit dengan memanfaatkan air limbah pengolahan gambir telah dilakukan. Penelitian dilakukan dengan variasi persentase penambahan tawas dan tunjung sebagai mordan masing-masing $0 \%, 2 \%, 4 \%$ dan $6 \%$ kedalam limbah cair pengolahan gambir. Penambahan tawas dan tunjung dilakukan pada penyamakan tahap II. Pengamatan terhadap kulit tersamak meliputi tampilan warna kulit yang dihasilkan, dan analisis sifat kimia dan sifat fisika kulit tersamak dengan mengacu kepada SNI 04631989-A. Hasil penelitian menunjukkan bahwa perlakuan pemakaian tawas dan tunjung sebagai mordan berpengaruh terhadap warna kulit tersamak. Pemakaian tawas memberikan warna kuning kemerahan sedangkan pemakaian tunjung memberikan warna hitam kehijauan pada kulit yang tersamak. Pemakaian tawas memberikan sifat kimia dan sifat fisika kulit yang lebih baik dari pada pemakaian tunjung. Hasil uji menunjukkan bahwa pemakaian tawas memberikan kelarutan tannin dalam air yang lebih rendah, kadar kulit mentah yang lebih kecil, tannin terikat lebih tinggi, kekuatan tarik lebih tinggi, kekuatan lentur/kemuluran yang lebih rendah dibanding dengan perlakuan pemakaian tunjung. Perlakuan persentase pemberian tawas lebih berpengaruh terhadap sifat fisik kekuatan tarik dan kekuatan lentur kulit tersamak. Semakin tinggi persentase tawas, maka semakin tinggi kekuatan tarik dan sebaliknya semakin rendah kekuatan lentur. Perlakuan optimum didapatkan pada penambahan tawas $2 \%$.
\end{abstract}

\begin{abstract}
Skin tanning research has been carried out by utilizing gambier processing wastewater. The study was conducted with a variation of the percentage of alum and tunjung addition as mordant respectively 0\%, 2\%, 4\% and 6\% into gambier processing wastewater. The addition of alum and tunjung is carried out in the tanning phase II. Observation of tanned skin includes the appearance of the resulting skin color, and the analysis of chemical and physical properties of tanned skin with reference to SNI 0463-1989-A. The results showed that the treatment of alum and tunjung as mordant affected the tanned skin color. The treatment of alum as mordant gave a reddish yellow color while the use of tunjung gave a greenish black color to the tanned skin. The use of alum gives the chemical and physical properties of the skin better than the use of tunjung. The test results show that the use of alum provides lower tannins solubility in water, lower raw skin content, higher tannin bound, higher tanning levels, higher tensile strength, higher flexural strength / elongation strength compared to the treatment of using tunjung. The percentage treatment of alum is more influential on the physical properties of tensile strength and flexural strength of tanned skin. The higher the percentage of alum, the higher the tensile strength, on the other hand the lower the flexural strength. The optimum treatment was obtained at $2 \%$ addition of alum.
\end{abstract}




\section{Pendahuluan}

Industri penyamakan kulit biasanya menggunakan bahan penyamakan sintetis. Bahan penyamak sintetis ini menggunakan proses krom yang menghasilkan limbah cair yang mengandung logam krom. Krom yang dihasilkan adalah krom bervalensi 3+ (trivalent) yang diperoleh dari proses penyamakan kulit tersebut. Limbah cair ini dapat membahayakan lingkungan karena trivalent dapat berubah valensi menjadi krom bervalensi 6+ (heksavalent) pada kondisi basa yang merupakan jenis limbah B3 yang dapat membahayakan kesehatan (Ardinal et al., 2014; G-star, 2018; Tegtmeyer and Kleban, 2013).

Sebagai alternatif untuk mengurangi dan menggantikan bahan penyamak krom ini, pada umumnya telah digunakan bahan penyamak pengganti yang ramah lingkungan dengan cara penyamakan kombinasi. Pada umumnya samak kombinasi menggunakan bahan penyamak nabati seperti mimosa, kayu akasia, kayu bakau dan kayu tingi (Cahyo et al., 2016; Herminiwati et al., 2015; Kasmudjiastuti, 2014; Ramadhan et al., 2016). Namun penggunaan mimosa juga akhirnya menjadi permasalahan, karena mimosa merupakan barang impor yang cukup mahal (Kasim et al., 2013). Sementara itu penyamakan secara nabati menggunakan kayu akasia dan bakau juga dapat berdampak buruk bagi kelestarian lingkungan, karena kedua jenis pohon ini termasuk yang dilindungi dandilestarikan. Pengambilan kulit kayu yang dilakukan secara terus menerus dapat mengakibatkan gangguan pertumbuhan pada pohon bahkan bisa membuat pohon menjadi mati. Akhir-akhir ini telah dilaporkan alternatif pengganti bahan penyamak yang ramah lingkungan untuk menggantikan bahan penyamak krom, akasia dan bakau tersebut dengan tanaman yang dibudidayakan seperti Gambir (Juliyarsi et al., 2013).

Di Sumatera Barat banyak terdapat tamanam gambir. Bahkan Provinsi Sumatera Barat saat ini merupakan penghasil gambir terbesar yaitu sekitar $90 \%$ dari total produksi gambir nasional dan merupakan pengekspor terbesar gambir dunia dengan jumlah ekspor lebih dari 80\% (Failisnur and Yeni, 2013). Namun selama ini industri penyamakan kulit belum terbiasa mengaplikasikan gambir untuk penyamakan kulit. Gambir telah dibudidayakan dan tersedia dalam jumlah yang relatif banyak sehingga mudah didapat. Gambir diperkirakan dapat digunakan sebagai pengganti bahan impor mimosa, bakau dan akasia (Juliyarsi et al., 2013). Beberapa penelitian tentang penggunaan gambir sebagai bahan pengganti penyamakan nabati dalam samak kombinasi telah dilaporkan. Diantaranya adalah gambir untuk penyamak kombinasi (Juliyarsi et al., 2013; Kasim et al., 2015, 2013; Setiawan et al., 2015) cube black gambir untuk penyamak kulit (Yeni et al., 2016).

Gambir yang dikenal dipasaran adalah eksrak kering dari ranting dan daun tanaman Uncaria gambir Roxb. Gambir merupakan tumbuhan yang termasuk dalam famili Rubiaceace dan komoditas perkebunan rakyat. Ekstrak mengandung katekin sebagai komponen utama serta beberapa komponen lain seperti asam kateku tanat, kuesertin, kateku merah, gambir flouresen, lemak dan lilin, pengunaan gambir yang umum dikenal dalam makan sirih sebagai campuran bahan untuk penambahan rasa nikmat, pada saat dimakan terasa pahit tetapi kemudian terasa manis dan dapat menyehatkan gigi, gusi dan tenggorokan (Achmad et al., 2012). Sejalan dengan berkembangnya industri yang mengedepankan konsep kembali ke alam (back to nature) gambir mulai banyak dibutuhkan sebagai bahan bahan obat.kosmetik, batik dan insektisida.

Gambir merupakan getah yang diperoleh dari ekstraksi panas daun dan ranting tanaman gambir yang diikuti pengempaan, sedimentasi, dan pasta yang terbentuk dicetak lalu dikeringkan. Gambir mengandung tannin sebanyak 51,14\% (Failisnur and Sofyan, 2019). Proses produksi gambir tersebut menghasilkan air limbah yang disebut limbah gambir. Menurut Sumatera Barat dalam angka, total produksi gambir Sumatera Barat selama tahun 2016 mencapai 14.220 ton. Dari jumlah tersebut akan dihasilkan lebih kurang 5.688.000 liter limbah cair per tahun. Selama ini limbah cair gambir yang merupakan hasil samping dari proses produksi gambir tersebut belum banyak dimanfaatkan. Sementara itu, air limbah ini masih mengandung tannin yang tinggi. Sekitar 9-11\% tannin terdapat dalam air limbah gambir. Hal ini terjadi karena sifat tannin yang mudah larut dalam air panas, sehingga tannin terdapat pada sisa air perebusan atau dari proses sedimentasi saat proses perebusan daun dan ranting tanaman gambir (Failisnur and Yeni, 2013). Kandungan tannin yang tinggi dalam limbah cair ini merupakan bahan yang dapat digunakan sebagai penyamakan kulit

Air limbah gambir berwarna coklat kemerahan sampai coklat kehitaman dengan kekentalannya $7-8^{\circ} \mathrm{Be}$ dan $\mathrm{pH}$ 4,5-5 (Failisnur and Yeni, 2013). Pada penelitian pemakaian air limbah gambir untuk pewarna kain sutera telah dilaporkan bahwa, agar warna limbah gambir dapat digunakan untuk pewarna kain dan warnanya memiliki kekuatan warna yang baik, maka perlu diberikan pembangkit warna dalam proses mordating. Pembangkit warna yang biasa digunakan adalah tawas, tunjung dan kapur. Masing-masing jenis mordan akan memberikan warna yang berbeda pula. Penggunaan mordan kapur, tawas dan tunjung masing-masing menghasilkan warna coklat kemerahan, kuning cerah dan hijau lumut (Failisnur et al., 2017; Sofyan et al., 2015).

Penelitian pemanfaatan air limbah gambir untuk penyamak kulit dengan samak kombinasi menggunakan pembangkit warna tawas dan tunjung dengan berbagai konsentrasi belum pernah dilaporkan. Selain itu diperkirakan ada beberapa keuntungan penggunaan tawas dan tunjung, diantaranya adalah dapat memberikan alternatif pewarnaan spesifik dan kualitas yang baik terhadap kulit tersaamak. Keuntungan lainnya adalah tawas dan tunjung termasuk zat yang aman bagi lingkungan, mudah didapat, dan harganya relatif murah. Untuk itu telah dilakukan memanfaatkan air limbah proses produksi gambir untuk penyamakan kulit sebagai penganti bahan sintetis dengan tujuan melihat pengaruh penggunaan tawas dan tunjung terhadap kulit tersamak. 


\section{Metode}

Bahan yang digunakan dalam penelitian ini adalah gambir kering, krom, mimosa, kulit kambing, air, kapur tohor $\left(\mathrm{Ca}(\mathrm{OH})_{2}\right)$, natrium sulfida $\left(\mathrm{Na}_{2} \mathrm{~S}\right)$, aquadest, asam sulfat pekat $\left(\mathrm{H}_{2} \mathrm{SO}_{4}\right)$, natrium karbonat $\left(\mathrm{Na}_{2} \mathrm{CO}_{3}\right)$, natrium bikarbonat $\left(\mathrm{NaHCO}_{3}\right)$, amonium sulfat (ZA), formaldehid $(\mathrm{Fa})$ teepol, oropon, preventol, garam $(\mathrm{NaCl})$, hexan, selenium mix, natrium hidroksida $(\mathrm{NaOH})$, dan indikator MMB. Bahan kimia yang digunakan dengan tingkat kemurnian tinggi (p.a) keluaran Merck Germany.

Peralatan yang digunakan dalam penelitian ini adalah drum penyamakan dengan kapasitas $10 \mathrm{~kg}$. Alat untuk pengujian fisik seperti kuat tarik, kemuluran, kuat sobek menggunakan Zwick/Roell 2020. Alat untuk pengujian tebal menggunakan SG 300. Alat untuk uji derajat penyamakan. Alat untuk pengujian suhu kerut menggunakan alat hasil rekayasa. Peralatan lain yang digunakan adalah gunting, pisau, kompor, baskom, oven, desikator, Erlenmeyer, cawan porselin, oven listrik, tanur, labu ukur $100 \mathrm{ml}$, pipet, Erlenmeyer 100 $\mathrm{ml}$, timbangan analitik, gelas piala, batang pengaduk, gelas ukur, pipet gondok, labu soklet, labu semprot, corong, penangas air, kertas saring,dan labu Kjedahl.

\subsection{Tahapan penelitian}

Penelitian ini dilakukan melalui dua tahap penyamakan yaitu Penyamakan kulit tahap I dengan pemakaian krom untuk white blue dan dilanjutkan dengan penyamakan kulit tahap II dengan perlakuan pencampuran air limbah pengolahan gambir dengan tawas dan tunjung masing-masing 0\%, 2\%, 4\% dan 6\%. Masing-masing perlakuan dilakukan 3 kali ulangan.

\subsubsection{Prosedur kerja penyamakan kombinasi Krom, limbah pengolahan gambir yang dicampur dengan tawas dan tunjung}

Prosedur kerja penyamakan kulit kambing dilakukan berdasarkan metode modifikasi dari prosedur penyamakan kulit Akademi Tehnologi Kulit Yogyakarta (2009), persentase bahan yang digunakan berdasarkan dari berat kulit setelah ditimbang untuk proses soaking dan liming.

Prosedur kerja penyamakan kombinasi krom dengan Limbah gambir adalah sebagai berikut:

1. Soaking (perendaman): air dimasukkan kedalam drum samak kapasitas $10 \mathrm{~kg}$ sebanyak $600 \%$, lalu ditambahkan $0.5 \%$ tepol dan ditambahkan $0.01 \%$ preventol, kemudian dimasukkan kulit, diputar selama 60 menit, kemudian dicuci dengan air mengalir.

2. Limming (Pengapuran): dimasukkan air sebanyak $200 \%$, ditambahkan $2 \%$ nartruim sulfida, ditambahkan $2 \%$ kapur kemudian diputar 30 menit, didiamkan 30 menit, kemudian ditambahkan kapur $2 \%$, ditambah $2 \%$ natrium sulfida kemudian diputar selama 30 menit, kemudian ditambah lagi kapur
$2 \%$,diputar 30 menit, cek $\mathrm{pH}=12$, kemudian di Over night.

3. Penimbangan untuk mencari Bloten (berat setelah bulu hilang). Untuk proses selanjutnya persentase penggunaan bahan berdasarkan berat bloten.

4. Deliming (buang kapur): $200 \%$ air, ditambah $0.5 \%$ ZA, kemudian diputar 30 menit, kemudian ditambahkan $0.5 \% \mathrm{Fa}$, diputar 30 menit. Cek pH, jika $\mathrm{pH}$ asam maka ditambahkan $\mathrm{NaOH}$ sampai $\mathrm{pH}$ 7, kemudian diputar 60 menit.

5. Bating (pengikisan protein), dilakukan dengan cara penyabunan lunak: $0.5 \%$ tepol, kemudian ditambahkan $0.5 \%$ oropon kemudian diputar selama 30 menit, kemudian dicuci hingga bersih.

6. Pikle (pengasaman): $80 \%$ air, ditambahkan $10 \%$ garam, kemudian diputar selama 10 menit, ditambahkan $0.5 \% \mathrm{Fa}$ dilarutkan 1:10, kemudian diputar selama 30 menit, kemudian tambahkan 1$1.5 \%$ asam sulfat, larutkan 1:10, kemudian dibagi 3 lalu Masukkan asam sulfat $(1,2,3)$ x 30 menit per larutan, kemudian diputar kembali selama 60 menit, dimasukkan $0.01 \%$ preventol, kemudian diputar 10 menit, ukur $\mathrm{pH}, \mathrm{pH}=3$

7. Penyamakan tahap I dengan menggunakan krom: Kulit pickle ditambahkan 6\%, kemudian diputar 120240 menit dalam drum samak, ditambahkan 1,5\% natrium karbonat, dilarutkan kemudian dibagi 3 dimasukkan larutan $\mathrm{Na}_{2} \mathrm{CO}_{3}(1,2,3)$ x 30 menit per larutan, diputar kembali selama 60 menit cek $\mathrm{pH}=4$, Kemudian dilakukan shrinkage, tidak susut direbus pada suhu $100^{\circ} \mathrm{C}$ selama 2 menit.

8. Pencucian dilakukan pencucian dengan air bersih dalam drum samak yang di putar selama 15 menit dengan 3 kali pengantian air.

9. Netralisir: $100 \%$ air, ditambah $1 \%$ natrium bikarbonat dilarutkan 1:10 dibagi 2. Masukkan larutan (1.2) x 30 menit per larutan, kemudian dicek $\mathrm{pH}=7$

10. Penyamakan tahap II dengan menggunakan limbah gambir divariasikan dengan tawas dan tunjung masing-masing $0 \%, 2 \%, 4 \%, 6 \%$

11. Ditambahkan asam formiat $1 \% 3$ kali 15 menit dilarutkan terlebih dahulu (fiksasi)

12. Dicuci dengan air mengalir untuk menghilangkan sisa zat penyamak yang masih melekat.

13. Dilakukan pengeringan dengan cara pementangan atau peregangan di udara terbuka dan menghindarkan dari panas langsung.

\subsubsection{Pengamatan kulit tersamak}

Dilakukan pengamatan warna yang dihasilkan, pengamatan secara kimia dan fisika, berdasarkan SNI 0463-1989-A terhadap kulit hasil penyamakan. Untuk pengamatan secara kimia meliputi pengamatan warna, parameter uji kadar air, kadar minyak, kadar zat larut dalam air, kadar abu, kadar zat kulit mentah dan kadar zat penyamak (tanin) terikat. Untuk pengamatan secara fisika dengan pengujian kekuatan tarik dan kekuatan lentur/kemuluran. 


\section{Hasil dan pembahasan \\ 3.1. Pengaruh terhadap warna}

Pemakaian tawas dan tunjung sebagai mordan pada penyamakan tahap ke 2 berpengaruh terhadap warna kulit tersamak yang dihasilkan. Seperti terlihat pada Gambar 1 dan 2, pemakaian tawas memberikan warna mengarah ke warna kuning kemerahan sedangkan pemakaian tunjung memberikan warna mengarah ke warna hitam kehijauan pada kulit yang tersamak. Tawas dan tunjung terbukti dapat digunakan sebagai zat pembangkit warna. Sehingga dapat menghasilkan warna yang lebih rata. Hal ini kemungkinan disebabkan karena tawas dan tunjung mempunyai sifat alkali basa. Penggunaan tawas dan tunjung dalam penyamakan kulit dapat menimbulkan warna dan kekuatan warna yang baik dan warna dapat masuk kedalam serat kulit. Sehingga diharapkan dapat meningkatkan kualitas kulit tersamak yang dihasilkan.

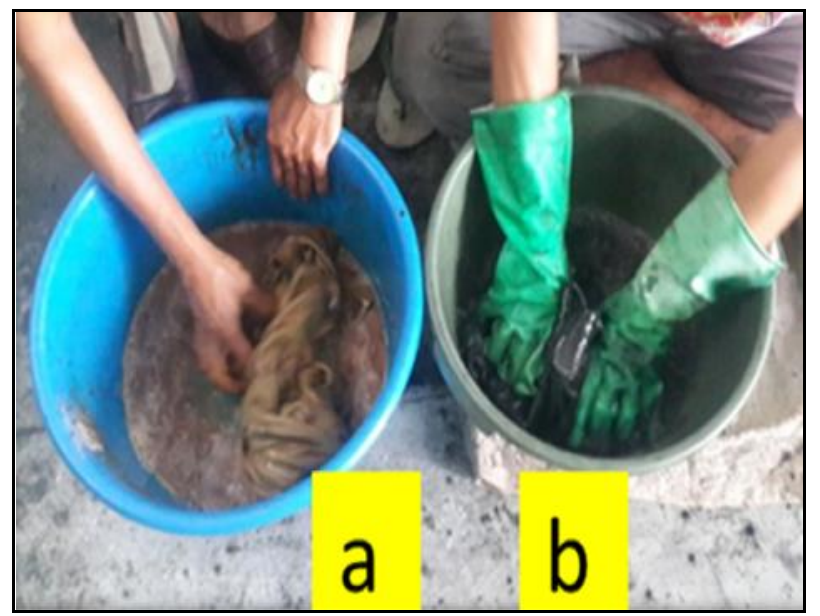

Gambar 1. Proses proses penyamakan tahap ke 2 menggunakan air limbah gambir dengan pembangkit warna tawas (a) dan tunjung (b)

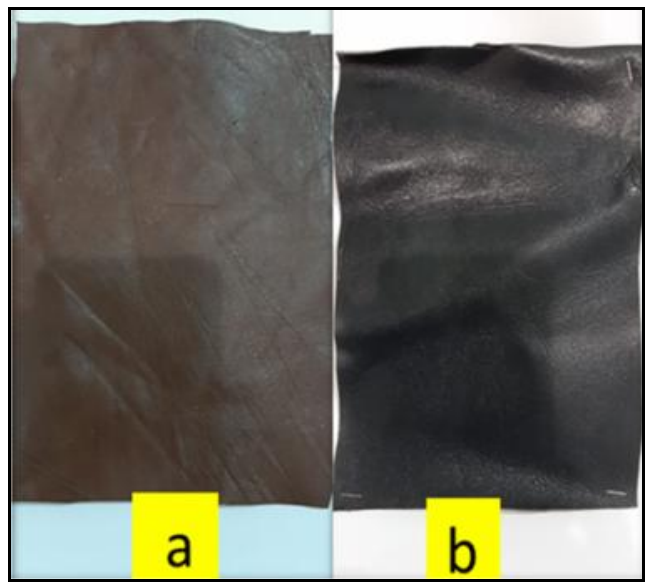

Gambar 2. Warna kulit tersamak yang dihasilkan dari proses penyamakan menggunakan air limbah gambir dengan pembangkit warna tawas (a) dan tunjung (b),

Warna yang dihasilkan hampir sama dengan hasil penelitian penggunaan air limbah gambir untuk pencelupan kain sutra dan katun dengan beberapa jenis mordan yang telah dilaporkan. Dimana kain yang dimordan dengan tawas menghasilkan warna kuning cerah dan yang dimordan dengan tunjung menghasilkan warna hijau lumut (Sofyan et al., 2015).

Perbedaan warna tersebut sebenarnya telah kelihatan pada saat proses penyamakan (Gambar 2). Namun perbedaan konsentrasi tidak begitu berpengaruh terhadap perbedaan warna, dimana penambahan tawas kedalam air limbah gambir untuk proses pencelupan memberikan warna coklat kekuningan, sedangkan penambahan tunjung, memberikan warna hitam kehijauan (Gambar 2). dengan adanya proses mordan meningkatkan interaksi antara pewarna dan serat melalui pembentukan kompleks koordinasi, yang akirnya menghasilkan penyerapan zat warna dan kestabilan pewarna yang lebih tinggi (Failisnur et al., 2017; Sofyan et al., 2015).

\subsection{Pengaruh terhadap kadar air}

Hasil analisis kadar air terhadap kulit tersamak dengan variasi limbah pengolahan gambir dengan penambahan tawas dan tunjung masing-masing $0 \%, 2 \%$, 4\%, 6\% dapat dilihat pada Gambar 3.

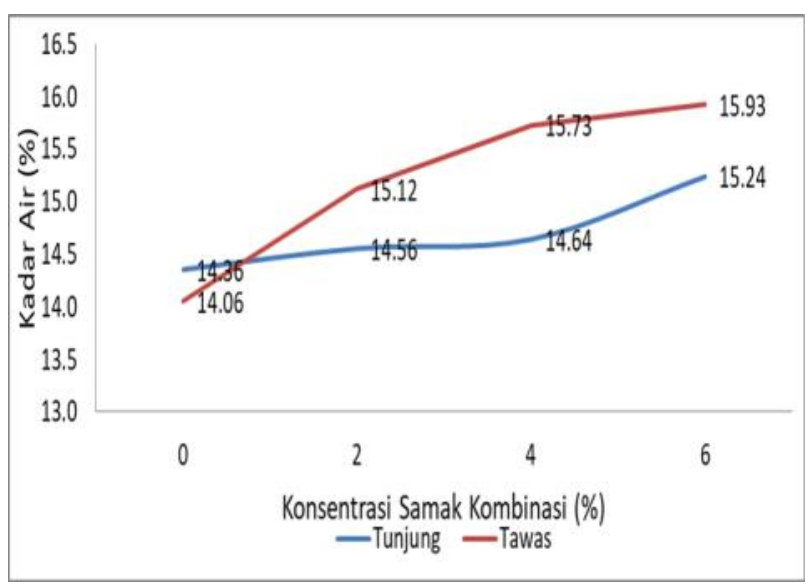

Gambar 3. Pengaruh perlakuan konsentrasi tawas dan tunjung dalam limbah pengolahan gambir sebagai penyamak terhadap kadar air kulit tersamak.

Hasil analisis kadar air kulit tersamak didapatkan data rata-rata berkisar dari $14,06 \%$ sampai $15,93 \%$. Kadar air terendah terdapat pada perlakuan penyamakan menggunakan limbah gambir yang tidak dikombinasikan dengan tunjung dan tawas yaitu dengan kadar air 14,06\%. Hal ini disebabkan karena limbah gambir masih mengandung tannin, dimana tanin dapat bereaksi dengan protein yang terdapat dalam kulit secara cepat. Dengan terjadinya ikatan tersebut dalam penyamakan kulit, menyebabkan kemungkinkan ada sebagian air yang dilepaskan secara cepat dari dalam kulit. Disamping itu, dengan penggunaan bahan penyamak limbah cair gambir tanpa campuran tawas dan tunjung juga mempengaruhi ikatan kolagen, air dan bahan penyamak. Penyamakan dengan menggunakan bahan penyamak nabati akan membentuk cross-linking dengan kolagen kulit, ikatan hidrogen dan ikatan kovalen yang menghasilkan kulit samak (Suparno and Evans, 2012). Nilai kadar air kulit juga dipengaruhi oleh sifat penetrasi (daya tembus) bahan penyamak ke dalam kulit, dimana kandungan zat penyamak (tanin) mulai berdifusi 
(menyebar) ke dalam kulit dan berikatan dengan seratserat kulit serta pada waktu yang sama melepaskan sejumlah air (Juliyarsi et al., 2013).

Kadar air tertinggi terdapat pada samak kombinasi limbah gambir dengan tawas $6 \%$ dengan kadar air $15,93 \%$. Semakin besar pengunaan tawas semakin tinggi kadar air. Hal ini diduga akibat penambahan tawas dalam jumlah yang banyak dalam bahan penyamak limbah gambir, dapat menyebabkan tertutupnya pori pori kulit karena Tawas $\left(\mathrm{Al}_{2}\left(\mathrm{SO}_{4}\right)_{3}\right)$ merupakan Garam logam, mudah bereaksi dengan kulit dan menyebabkan air tertahan dalam kulit.

Jika dibandingkan dengan SNI kulit samak kombinasi, kadar air kulit hasil penelitian samak kombinasi limbah gambir-tawas dan limbah gambirtunjung yang dilakukan sudah dapat memenuhi standar. Menurut SNI 0463-1989-A, kadar air kulit penyamakan maksimal $18 \%$.

\subsection{Pengaruh terhadap kadar abu}

Hasil analisis kadar abu terhadap kulit tersamak dengan variasi limbah pengolahan gambir dengan persentase penambahan tawas dan tunjung masingmasing 0\%, 2\%, 4\%, 6\% dapat dilihat pada Gambar 4 . Kadar abu kulit tersamak cenderung semakin tinggi dengan kenaikan prosentase penambahan tawas dan tunjung. Namun kenaikan tersebut tidak terlalu berbeda. Hal ini dapat dilihat pada Gambar 4 yang menunjukkan terjadi peningkatan kadar abu berturut-turut $6,81 \%$, $7,10 \%, 7,22 \%$ dan $6,71 \%, 6,91 \%$ 6,94\% untuk masingmasing penambahan tawas dan tunjung $2 \%, 4 \%$, dan $6 \%$. Sedangkan kadar abu terendah didapatkan $6,70 \%$, pada perlakuan penyamakan penggunaan limbah gambir tanpa penambahan tawas dan tunjung (penambahan 0\%).

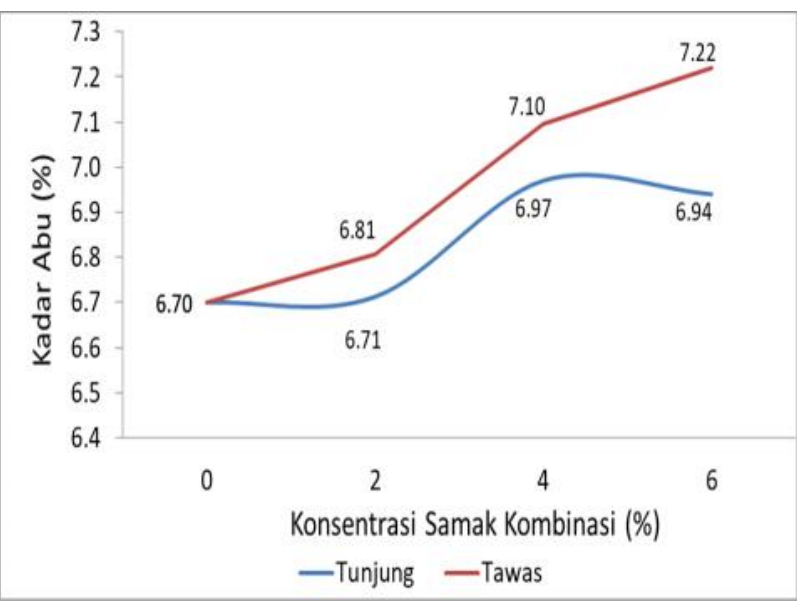

Gambar 4. Pengaruh perlakuan konsentrasi tawas dan tunjung dalam limbah pengolahan gambir sebagai penyamak terhadap kadar abu kulit tersamak.

Abu adalah sisa pembakaran dari kulit tersamak setelah diambil minyak dan zat larut dalam air. Dalam kadar abu terkandung unsur-unsur anorganik yang tidak bisa larut dalam air. Kulit hewan yang belum disamak mengandung mineral sekitar $0.5 \%$ yang terdiri dari $\mathrm{K}$, $\mathrm{Ca}, \mathrm{Mg}, \mathrm{Fe}$ dan Na (Juliyarsi et al., 2013). Kulit samak mengandung mineral yang jumlahnya lebih tinggi seiring dengan peningkatan konsentrasi zat penyamak kombinasi limbah gambir-tawas dan limbah gambirtunjung Hal ini disebabkan karena terjadinya pengikatan unsur-unsur mineral oleh protein kulit dalam proses penyamakan tahap I serta adanya ikatan mineral Ca pada proses pengapuran (Juliyarsi et al., 2013).

Jika dibandingkan dengan standar mutu SNI 04631989-A untuk penggunaan penyamakan kombinasi, kulit tersamak menggunakan campuran limbah gambir dengan tawas dan tunjung, memiliki kadar abu yang lebih tingi dari standar dimana batas maksimal yang dipersyaratkan adalah 5\%.

\subsection{Pengaruh terhadap kadar lemak}

Hasil analisis kadar lemak terhadap kulit tersamak dengan variasi limbah pengolahan gambir dengan persentase penambahan tawas dan tunjung masingmasing 0\%, 2\%, 4\%, 6\% dapat dilihat pada Gambar 5 . Analisis kadar lemak menunjukkan kandungan lemak yang terdapat dalam kulit setelah disamak. Lemak yang terukur merupakan lemak yang terdapat dari dalam kulit tersamak. Data hasil analisis lemak kulit samak kombinasi limbah pengolahan gambir dengan tawas dan tunjung berkisar antara 5,60\% sampai 5,65\%. Hasil penelitian ini dapat menenuhi standar mutu SNI 04631989-A yang mensyaratkan batas maksimal kandungan minyak dalam kulit tersamak adalah 3-8\%.

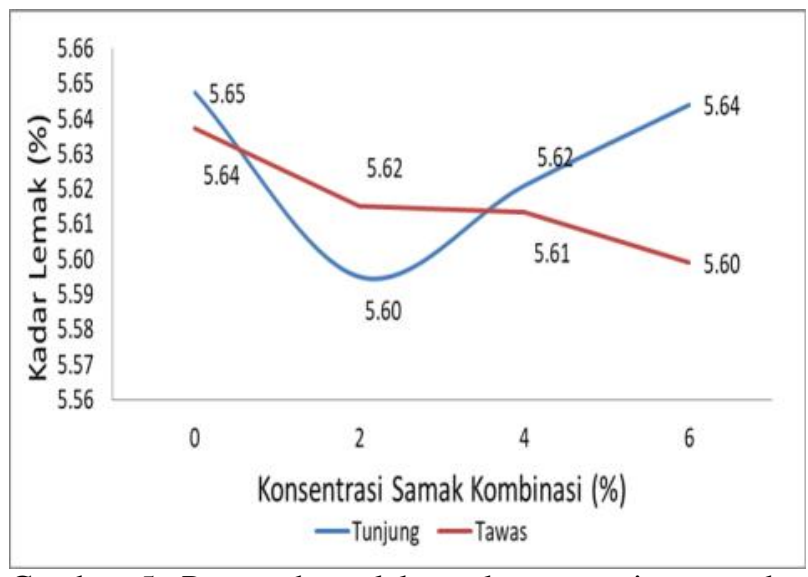

Gambar 5. Pengaruh perlakuan konsentrasi tawas dan tunjung dalam limbah pengolahan gambir sebagai penyamak terhadap kadar lemak kulit tersamak.

Pada perlakuan pemakaian tawas, kadar lemak kulit tersamak semakin rendah dengan semakin tingginya konsentrasi penambahan tawas. Sebaliknya pada perlakuan pemakaian tunjung, Kadar lemak kulit tersamak semakin tinggi dengan semakin tingginya konsentrasi (Gambar 5). Namun kenaikan dan penurunan kadar lemak kulit tersamak tersebut tidak jauh berbeda. Hal ini terjadi diduga akibat pengaruh pada saat proses pembuangan lemak. Pada proses pembuangan lemak digunakan bahan pembantu seperti Teepol, Baymol A, Sandopan DTC atau Resolin NCP yang fungsinya untuk mengemulsikan lemak sehingga lemak mudah untuk dilarutkan (Juliyarsi et al., 2013)

Rendahnya kadar lemak yang terdapat dalam kulit tersamak juga dapat disebabkan pada saat pembersihan lemak. Sebelum dilakukan proses penyamakan kulit dengan menggunakan pisau pembersih lemak 
(degreasing) dimana pada proses ini lemak dibuang semaksimal mungkin. Pembuangan lemak yang sempurna akan membantu proses penetrasi bahan penyamak kedalam kulit lebih lancar karena tidak terhambat oleh gumpalan-gumpalan lemak pada kulit. kandungan lemak pada kulit terdapat sekitar 7-8\% yang sebagian besar akan dibuang sebelum melakukan penyamakan, beberapa pengaruh yang mengakibatkan tingginya kadar lemak yang terdapat pada kulit dapat menghalangi penetrasi zat penyamak kedalam kulit, selain itu juga mengakibatkan tidak meratanya warna pada permukaan kulit sehingga menurunkan kualitas kulit tersamak. (Juliyarsi et al., 2013)

\subsection{Pengaruh terhadap kadar zat larut dalam air}

Hasil analisis kadar zat larut dalam air terhadap kulit tersamak dengan variasi limbah pengolahan gambir dengan persentase penambahan tawas dan tunjung masing-masing 0\%, 2\%, 4\%, 6\% dapat dilihat pada Gambar 6. Data hasil penelitian kadar zat larut dalam air pada penyamakan gambir menunjukkan hasil berkisar antara $2,03 \%$ sampai $3,71 \%$.

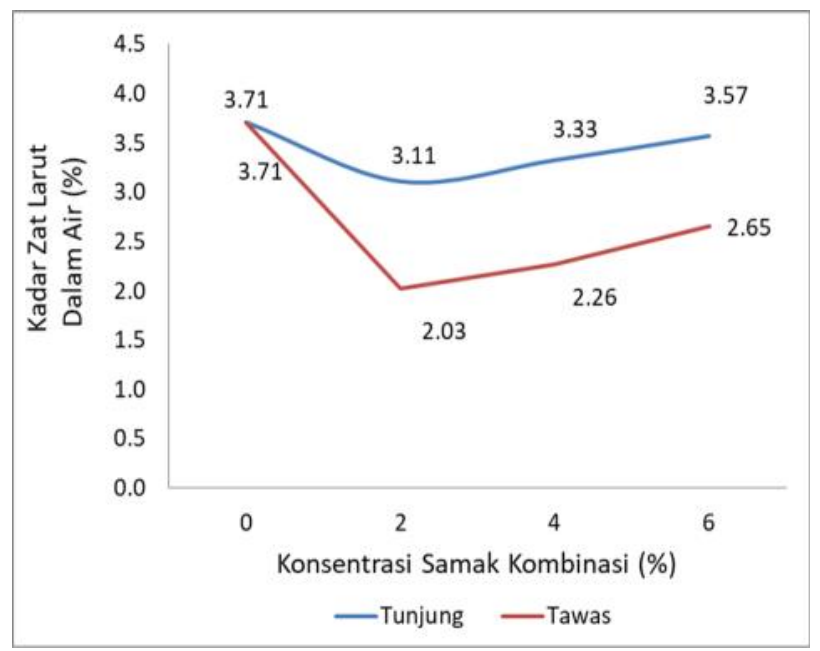

Gambar 6. Pengaruh perlakuan konsentrasi tawas dan tunjung dalam limbah pengolahan gambir sebagai penyamak terhadap kadar zat larut dalam air kulit tersamak.

Kadar zat larut dalam air merupakan zat penyamak yang larut kembali dalam air setelah dilakukan perendaman dengan air setelah penyamakan kulit. Hal ini berkaitan dengan tanin terikat dalam kulit tersamak. dimana tanin akan bereaksi dengan protein kulit dan kemudian mengisi ruang kosong diantara serat kulit. Dalam struktur kulit tersamak terdapat material yang terikat dan yang tidak berikatan baik dengan kolagen kulit maupun dengan bahan penyamak itu sendiri. Senyawa tanin yang berfungsi sebagai bahan penyamak sebagian akan berikatan dengan kolagen kulit, kemudian akan terbentuk ikatan hidrogen dengan sesama bahan penyamak, sehingga zat penyamak tersebut masih dapat larut dalam air (Juliyarsi et al., 2013).

Selama proses penyamakan berlangsung terjadi 2 tahap dalam reaksinya yaitu, tahap pertama terjadinya reaksi antara gugus hidroksil yang terdapat dalam zat penyamak nabati dengan kolagen, tahap kedua diikuti oleh reaksi ikatan dari molekul zat penyamak dengan molekul zat penyamak lainnya yang sama sampai seluruh ruang kosong yang terdapat diantara rantai kolagen terisi seluruhnya (Purnomo, 1991).

Pada Gambar 6 terlihat kelarutan zat dalam air tidak jauh berbeda. Kelarutan zat tertinggi didapatkan pada perlakuan limbah gambir tanpa campuran tawas dan tunjung $(0 \%)$ yaitu $3,71 \%$, sedangkan yang terendah didapatkan pada perlakuan dengan Tawas 2\% dan tunjung $2 \%$ yaitu masing-masing 2,03\%, dan 3,11\%. Kemungkinan pada perlakuan $0 \%$ disebabkan karena kurang kuatnya ikatan antara tanin dengan kalogen pada kulit. Diduga tannin mudah terlepas setelah dilakukan perendaman dalam air, karena pada perlakuan ini tidak ada bahan mordanting sebagai pengikat yang yang kuat dengan kulit. Sementara itu penambahan mordanting tawas dan tunjung juga mempunyai batas optimum. Terlihat semakin tinggi persentase penambahan tawas dan tunjung, semakin tinggi pula kadar zat larut dalam air. Diduga masih ada sisa campuran tawas dan tunjung yang tidak dapat beraksi dengan kalogen kulit. Pada Gambar 6 juga terlihat bahwa pemakaian tawas lebih baik dari tunjung, dimana dapat memberikan kadar zat larut dalam air yang lebih rendah dibandingkan dengan pemakaian tunjung. Kulit tersamak dengan limbah gambir yang dikombinasikan dengan tawas dan tunjung yang dihasilkan dapat memenuhi syarat mutu kulit samak nabati SNI 0463-1989-A denga batas maksimum $6 \%$.

\subsection{Pengaruh terhadap kadar zat kulit mentah}

Data hasil penelitian kadar zat kulit mentah samak kombinasi limbah gambir pada berbagai variasi menunjukkan hasil berkisar antara 7,45-7,61\%. Zat kulit mentah pada kulit samak merupakan protein kulit yang belum bereaksi dengan senyawa penyamak atau taning agent, dimana semakin banyak tanin yang terikat maka zat kulit mentah akan menurun. Penyamakan kombinasi menggunakan limbah gambir akan membentuk ikatan cross-linking yang terjadi antara kolagen dengan bahan penyamak. Penyamakan kombinasi dengan menggunakan bahan penyamak nabati memberikan efek sinergis untuk membentuk ikatan yang stabil. Hal ini juga mengindikasikan bahwa ikatan kovalen memiliki peranan penting dalam penyamakan kombinasi (Juliyarsi et al., 2013; Suparno and Evans, 2012).

Pada Gambar 7 terlihat rata-rata kadar zat kulit mentah pada kulit tersamak mengunakan limbah gambir tanpa dicampur dengan tawas dan tunjung (0\%) menunjukkan hasil 7,61\%, yang lebih tinggi dibandingkan dengan pemakaian campuran tawas dan tunjung $2 \%, 4 \%, 6 \%$. Hal ini menunjukkan limbah gambir dicampur dengan tawas dan tunjung akan menurunkan kadar zat kulit mentah, yang ditandai dengan banyaknya zat penyamak berdifusi kedalam kulit dan mengurangi zat kulit mentah.

Pada Gambar 7 juga terlihat bahwa pemakaian tawas dan tunjung memberikan hasil kadar zat kulit mentah tidak jauh berbeda. Namun persentase penambahan tawas dan tunjung berpengaruh terhadap senyawa tanin yang berikatan dengan kolagen kulit. Semakin tinggi persentase penambahan tawas dan tunjung, maka 
semakin rendah kadar zat kulit mentah. Jika dibandingkan dengan standar SNI 0463-1989-A, kadar zat kulit mentah pada penyamakan kombinasi limbah gambir dengan tawas dan tunjung yang dihasilkan, sudah dapat memenuhi standar, dimana maximum $10 \%$.

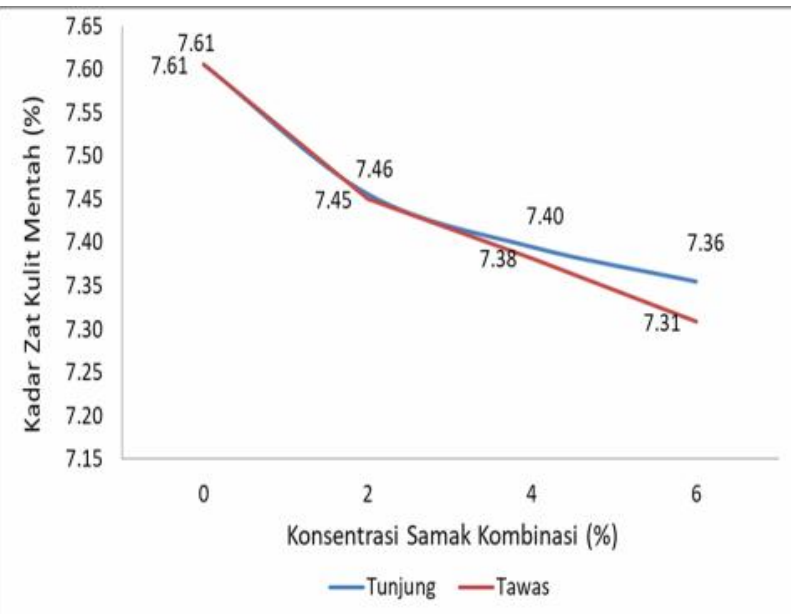

Gambar 7. Pengaruh perlakuan konsentrasi tawas dan tunjung dalam limbah pengolahan gambir sebagai penyamak terhadap kadar zat kulit mentah kulit tersamak

\subsection{Pengaruh terhadap kadar tanin terikat}

Tanin terikat pada kulit samak pada berbagai variasi limbah gambir pada berbagai tingkat perlakuan dengan tunjung dan tawas tertera pada Gambar 8 .

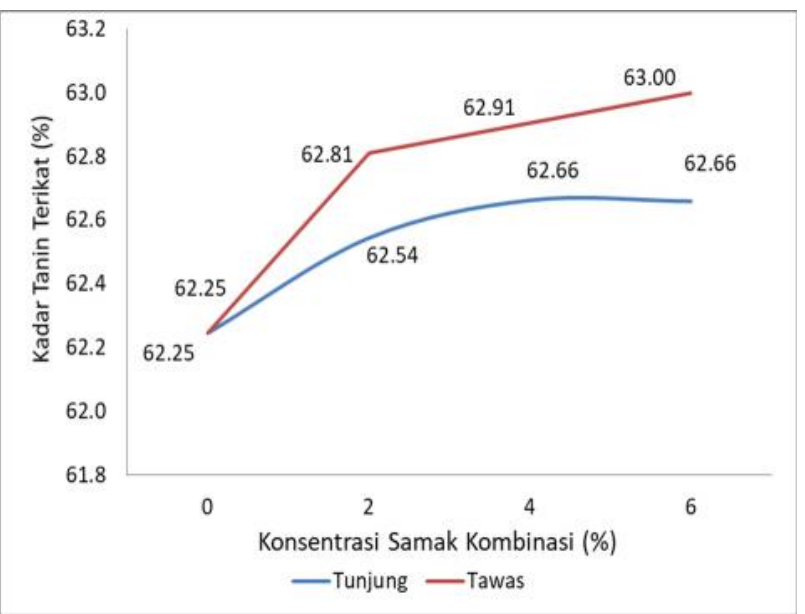

Gambar 8. Pengaruh perlakuan konsentrasi tawas dan tunjung dalam limbah pengolahan gambir sebagai penyamak terhadap Tanin terikat kulit tersamak

Jika dilihat dari rata-rata tanin terikat menunjukkan hasil antara yaitu 62,25\% dan 63,00\%. Pada limbah gambir tanpa campuran $(0 \%)$, tanin terikat yang didapat lebih rendah dari perlakuan lain dibandingkan dengan perlakuan campuran limbah gambir-tawas dan limbah gambir-tunjung. Semakin tinggi campuran tawas dan tunjung semakin tinggi kandungan tanin terikat pada kulit. Kadar zat penyamak terikat dipengaruhi oleh sifat dan kandungan zat penyamak yang digunakan. Peningkatan kadar zat penyamak terikat disebabkan oleh zat penyamak limbah gambir yang dicampur dengan tawas dan tunjung yang mudah berpenetrasi ke dalam kulit (Kasim et al., 2012). Konsentrasi zat penyamak yang lebih tinggi akan menyebabkan reaksi ikatan zat penyamak nabati (gambir-tawas dan gambir-tunjung) dengan protein kulit akan lebih cepat. Selain itu, perbedaan konsentrasi zat penyamak gambir yang terdapat diluar kulit dan cairan yang ada didalam kulit berpengaruh terhadap difusi bahan penyamak kedalam kulit sehingga membentuk ikatan dengan kolagen kulit (Juliyarsi et al., 2013).

Selama proses penyamakan berlangsung terjadi reaksi antara gugus hidroksil yang terdapat dalam bahan penyamak dengan struktur kolagen kemudian diikuti dengan ikatan dari molekul zat penyamak dengan molekul zat penyamak lainnya sampai ruang kosong diantara rantai kolagen terisi seluruhnya (Purnomo, 1991). Jika dibandingkan dengan standar kulit samak kombinasi sudah memenuhi standar SNI 0463-1989-A yaitu minimal 1,5\%. Pada Gambar 8 juga terlihat kadar tanin terikat samak kombinasi limbah gambir dengan tawas lebih tinggi dibandingkan limbah gambir dan tunjung, tetapi perbedaannya tidak terlalu jauh. Semakin tinggi penambahan tawas, maka semakin tinggi tanin terikat dihasilkan. Hal ini menunjukan pengunaan tawas lebih baik dibandingkan tunjung.

\subsection{Pengaruh terhadap kekuatan tarik kulit}

Hasil pengukuran fisik kekuatan tarik kulit tersamak pada berbagai tingkat perlakuan konsentrasi yang disamak kombinasi limbah gambir dengan tunjung dan tawas konsentrasi $0 \% 2 \%, 4 \%$ dan $6 \%$ terlihat pada Gambar 9. Sifat fisik kekuatan tarik kulit tersamak dengan berbagai konsentrasi penambahan limbah gambir dengan tawas dan tunjung dapat dilihat pada Gambar 9. Terlihat bahwa kekuatan tarik berkisar antara 273,74$329,32 \mathrm{~kg} / \mathrm{cm}^{2}$. Pada penyamakan dengan mengunakan limbah gambir tanpa tawas dan tunjung (0\%) memberikan hasil kekuatan tarik kulit yang paling rendah yaitu $273,74 \mathrm{~kg} / \mathrm{cm}^{2}$. sedangkan rata-rata kekuatan tarik kulit samak menggunakan limbah gambir dicampur dengan tawas menujukkan kekuatan tarik yang lebih tinggi dibandingkan dengan campuran tunjung. Peningkatan penggunaan gambir dengan tawas menghasilkan kekuatan tarik yang tinggi.

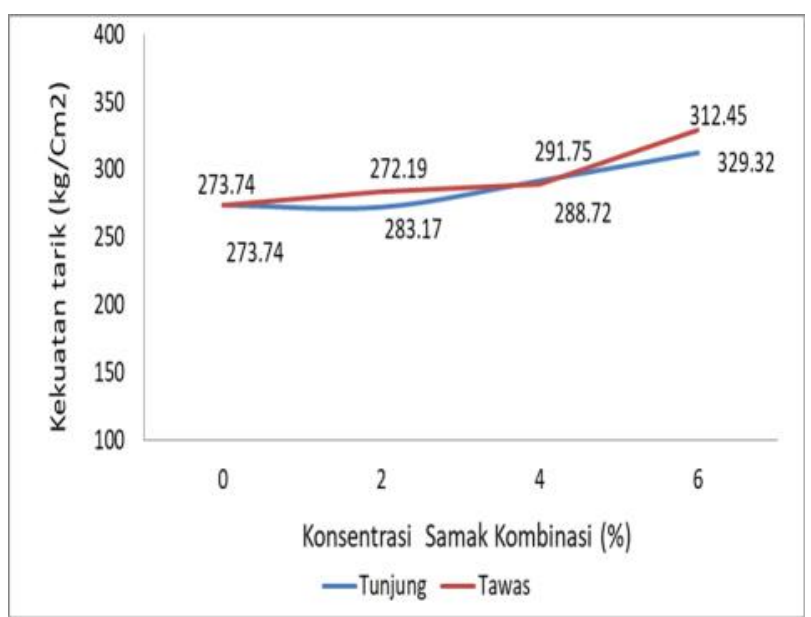

Gambar 9. Pengaruh perlakuan konsentrasi tawas dan tunjung dalam limbah pengolahan gambir sebagai penyamak terhadap kekuatan tarik kulit tersamak 
Kulit yang disamak dengan menggunakan bahan penyamak nabati akan memberikan hasil yang kurang tahan terhadap panas, kulitnya agak kaku, namun empuk dan memberikan sifat kulit yang berisi (padat), warna coklat dan kekuatan tariknya tinggi. Diduga molekulmolekul bahan penyamak pada samak nabati tidak sempurna mengikat protein kolagen yang ada pada ,kulit dibandingkan dengan proses samak mineral (Kasim et al., 2012; Purnomo, 1991). Jika dibandingan dengan standar hasil kekuatan tarik kulit pada semua perlakuan memenuhi standar kualitas kulit menurut SNI 04631989-A kulit kambing samak kombinasi yaitu minimum $75 \mathrm{~kg} / \mathrm{cm}^{2}$.

\subsection{Pengaruh terhadap kemuluran kulit}

Kemuluran kulit adalah pertambahan panjang kulit pada saat ditarik sampai putus dibagi dengan panjang semula dan dinyatakan dalam persen. Sifat fisik kemuluran kulit tersamak dengan berbagai konsentrasi penambahan limbah gambir dengan tawas dan tunjung dapat dilihat pada Gambar 10. Terlihat bahwa kemuluran kulit berkisar antara $22,64-25,01 \mathrm{~kg} / \mathrm{cm}^{2}$

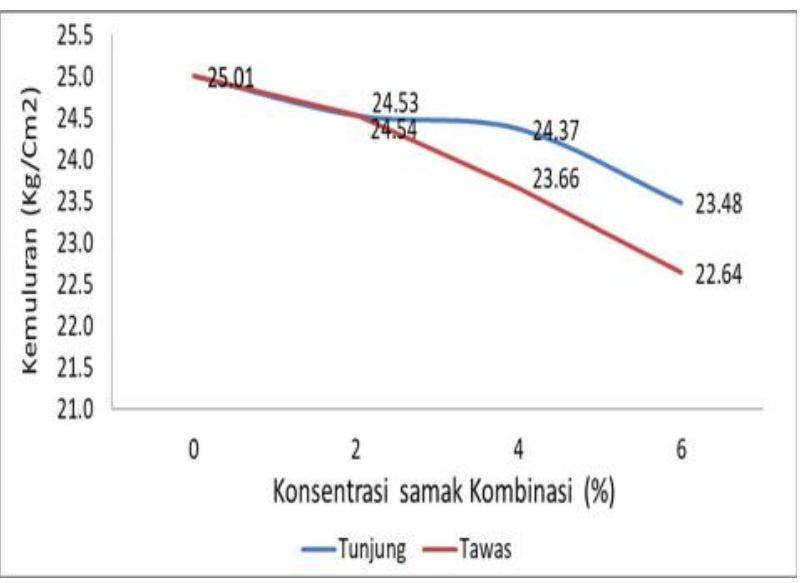

Gambar 10. Pengaruh perlakuan konsentrasi tawas dan tunjung dalam limbah pengolahan gambir sebagai penyamak terhadap kemuluran kulit tersamak

Kemuluran kulit tersamak limbah gambir-tawas lebih rendah dibandingkan dengan limbah gambir - tunjung. Dimana semakin tinggi konsentrasi pemakaian tawas semakin rendah kemuluran. Kemuluran kulit berkaitan dengan kelemasan/elastisitas kulit yang dihasilkan. Elastin merupakan protein fibrous yang membentuk serat-serat yang sangat elastis karena mempunyai rantai asam amino yang membentuk sudut. Kemuluran kulit tersamak menunjukkan kemampuan mulur kulit, semakin panjang ukuran kulit pada saat putus, maka nilai kekuatan regang yang dihasilkan semakin besar (Ramadhan et al., 2016; Setiawan et al., 2015).

Kemuluran kulit dipengaruhi oleh komposisi protein serat didalam kulit atau kondisi awal kulit dan Proses bating, sehingga bahan penyamak tidak mempengaruhi kemuluran kulit. Proses bating yang kurang baik akan menyebabkan kulit menjadi keras dan mudah patah sehingga kemuluranya tinggi. Jika serabut-serabut protein kulit tegak dan rapat, kulit akan mempunyai daya kemuluran yang rendah, tetapi jika serabut-serabut kulit letaknya horizontal dan anyaman tidak rapat maka kemuluran akan tinggi (Kasim et al., 2013).

Selain itu, faktor yang dapat mempengaruhi kemuluran kulit adalah ketebalan kulit, jenis kelamin dan umur hewan. Tebal kulit tergantung dari umur dan spesies asal hewan. Jenis kelamin dan umur hewan merupakan salah satu faktor yang dapat mempengaruhi daya tahan regang pada struktur jaringan kulit. Hewan yang berkelamin jantan kulit tersamaknya memiliki kekuatan regang yang lebih kecil dibanding hewan berkelamin betina. Begitu pula dengan hewan yang berumur lebih tua, kekuatan regang kulitnya lebih kecil dibanding yang berumur lebih muda.

Jika dibandingkan dengan standar hasil penelitian samak kombinasi limbah gambir-tunjung dan limbah gambir-tawas untuk semua perlakuan memenuhi standar SNI 0463-1989-A kulit kambing tersamak dengan standar kemuluran maksimal adalah $25 \%$.

\section{Kesimpulan}

Dari hasil penelitian yang telah dilakukan dapat disimpulkan bahwa hasil penelitian menunjukan bahwa limbah pengolahan gambir yang diperlakukan dengan pemakaian tawas dan tunjung sebagai mordan berpengaruh terhadap warna kulit tersamak. Pemakaian tawas memberikan warna kuning kemerahan sedangkan pemakaian tunjung memberikan warna hitam kehijauan pada kulit yang tersamak. Pemakaian tawas memberikan sifat kimia dan sifat fisika kulit tersamak yang lebih baik dari pada pemakaian tunjung. Hasil uji menunjukkan bahwa pemakaian tawas memberikan kelarutan tannin dalam air yang lebih rendah, kadar kulit mentah yang lebih kecil, tannin terikat lebih tinggi, kekuatan tarik lebih tinggi dan kekuatan lentur/kemuluran yang lebih rendah dibanding dengan perlakuan pemakaian tunjung.

Perlakuan persentase pemberian tawas lebih berpengaruh terhadap sifat fisik kekuatan tarik dan kekuatan lentur kulit tersamak Semakin tinggi persentase tawas, maka semakin tinggi kekuatan tarik dan sebaliknya semakin rendah kekuatan lentur. Perlakuan optimum didapatkan pada pencampuran tawas $2 \%$. Dengan penggunaan tawas dan tunjung dalam penyamakan kulit didapatkan selain akan menimbulkan warna dan kekuatan warna yang baik dan zat warna yang masuk kedalam serat kulit juga dapat meningkatkan kualitas kulit tersamak yang dihasilkan. Keutamaan lain dengan penambahan tawas dan tunjung sebagai pembangkit warna pada penyamakan, adalah karena zat tersebut aman bagi lingkungan, mudah didapat, harganya relatif murah. serta terbukti dapat digunakan sebagai zat pembangkit warna dan dapat menghasilkan warna yang lebih rata, disebabkan tawas dan tunjung mempunyai sifat alkali basa. 


\section{Daftar pustaka}

Achmad, A., Kasim, J., Suan, T.K., Amat, R.C., Seey, T.L., 2012. Equilibrium, kinetic and thermodynamic studies on the adsorption of direct dye onto a novel green adsorbent developed from Uncaria gambir extract. J. Phys. Sci. 23, 1-13.

Ardinal, A., Salmariza, S., Kasim, A., 2014. Perilaku krom dalam limbah cair penyamakan kombinasi krom-gambir dan krom-mimosa pada penyamakan kulit. J. Litbang Ind. 4, 59-66. doi:10.24960/jli.v4i1. 646.59-66

Cahyo, S.D., Agustini, T.W., Sumardianto, S., 2016. Pengaruh penyamakan kombinasi mimosa (tanning) dengan konsentrasi zirkonium yang berbeda (retanning) terhadap kualitas fisik kulit ikan Nila. J. Pengolah. dan Bioteknol. Has. Perikan. 5, 45-51.

Failisnur, F., Sofyan, S., 2019. Karakteristik kain batik hasil pewarnaan menggunakan pewarna alam gambir (Uncaria Gambir Roxb). Pros. Semin. Nas. Has. Litbangyasa Ind. II 2, 228-235.

Failisnur, F., Sofyan, S., Kumar, R., 2017. Efek pemordanan terhadap pewarnaan menggunakan kombinasi limbah cair gambir dan ekstrak kayu secang pada kain rayon dan katun. J. Litbang Ind. 7, 83-100. doi:10.24960/jli.v7i2.3541.93-100

Failisnur, Yeni, G., 2013. Stabilisasi limbah cair hasil pengolahan gambir dan aplikasinya sebagai pewarna pada kain sutera. Biopropal Ind. 4, 7-16.

G-star, R., 2018. Guideline for leather manufacturers. diperoleh kembali dari https://img2.gstar.com/image/upload/v01/CSR/PDF/Guide_for_Le ather_Manufacturers_Version_1.0.pdf bulan September 2019.

Herminiwati, H., Waskito, S., Purwanti, C.M.H., Prayitno, P., Ningsih, D., 2015. Pembuatan bahan penyamak nano nabati dan aplikasinya dalam penyamakan kulit. Maj. Kulit, Karet, dan Plast. 31, 15-22. doi:10.20543/mkkp.v31i1.180

Juliyarsi, I., Novia, D., Helson, J., Helson, J., 2013. Kajian penambahan gambir sebagai bahan penyamak nabati terhadap mutu kimiawi kulit Kambing. J. Peternak. Indones. Indonesian J. Anim. Sci. 15, 3545. doi:10.25077/jpi.15.1.35-45.2013

Kasim, A., Asben, A., Mutiar, S., 2015. Kajian kualitas gambir dan hubungannya dengan karakteristik kulit tersamak. Maj. Kulit, Karet, dan Plast. 31, 55-63. doi:10.20543/mkkp.v31i1.220
Kasim, A., Novia, D., Mutiar, S., Pinem, J., 2013. Karakterisasi kulit kambing pada persiapan penyamakan dengan gambir dan sifat kulit tersamak yang dihasilkan. Maj. Kulit, Karet, dan Plast. 29, 111. doi:10.20543/mkkp.v29i1.213

Kasim, A., Nurdin, H., Mutiar, S., 2012. Aplikasi gambir sebagai bahan penyamak kulit melalui penerapan penyamakan kombinasi. J. Litbang Ind. 2, 55-62. doi:10.24960/jli.v2i2.600.55-62

Kasmudjiastuti, E., 2014. Karakterisasi kulit kayu tingi (Ceriops tagal) sebagai bahan penyamak nabati. Maj. Kulit, Karet, dan Plast. 30, 71-77. doi:10.20543/ mkkp.v30i2.128

Purnomo, E., 1991. Pengetahuan dasar teknologi penyamakan kulit. Akademi Teknologi Kulit. Departemen Perindustrian., yogyakarta.

Ramadhan, V.G., Riyadi, P.H., Wijayanti, I., 2016. Aplikasi kulit kayu mangrove (Rhizopora Sp.) sebagai alternatif pewarna alami pada kulit samak ikan Nila (Oreochromis Niloticus). Pros. Semin. Nas. Kulit, Karet dan Plast. 5, 115-128.

Setiawan, A., Riyadi, P.H., Sumardianto, -, 2015. Pengaruh penggunaan gambir (uncaria gambier) sebagai bahan penyamak pada proses penyamakan kulit terhadap kualitas fisik kulit ikan nila (oreochromis niloticus). J. Pengolah. dan Bioteknol. Has. Perikan. 4, 124-132.

Sofyan, Failisnur, Salmariza, 2015. Pengaruh perlakuan limbah dan jenis mordan kapur, tawas dan tunjung terhadap mutu pewarnaan kain sutera dan katun menggunakan limbah cair gambir. J. Litbang Indsutri 5, 79-89. doi:10.24960/jli.v5i2.668.79-89

Suparno, O., Evans, A.D.C. dan C.S., 2012. Teknologi baru penyamakan kulit ramah lingkungan: penyamakan kombinasi menggunakan penyamak nabati, naftol dan oksazolidin. J. Agroindustrial Technol. 18, 79-84.

Tegtmeyer, D., Kleban, M., 2013. Chromium and leather research a balanced view of scientific facts and figures. Di peroleh kembali dari https://www.google.com/search?client=firefox-b-d\& $\mathrm{q}=$ Chromium + and + leather+research $+-+\mathrm{a}+$ balanced + vie+of+scientific+facts+and+figures.+International+ Union+o.

Yeni, G., Syafruddin, D., Kasim, A., 2016. Pengujian kemampuan daya samak cube black dan limbah cair gambir terhadap mutu kulit tersamak. J. Litbang Ind. 6, 73-82. doi:10.24960/jli.v6i1.1124.73-82 